\title{
Government and the military in Papua New Guinea
}

\section{Abstract for chapter 10}

\section{Author: R. J. May}

Contrary to pessimistic prediction, after independence Papua New Guinea's democratic system prospered, and in the absence of external threat the military languished. But within a decade of independence, growing problems of lawlessness and disorder began to threaten the position of national political leaders who started to call for an expanded role of the Defence Force in assisting police to maintain internal security.

The author details the colonial heritage, which led to the formation of the military and their role in post-independence Papua New Guinea. He also examines the military-civil relations in the independent state, claiming that the military's subordination to civilian authority is fairly well assured in the foreseeable future.

\section{Keywords}

'law and order', army, civil-military relations, democracy, military intervention, Papua New Guinea Defence Force (PNGDF) 


\title{
10
}

\section{GOVERNMENT AND THE MILITARY \\ IN PAPUA NEW GUINEA}

\author{
R.J. May
}

On the eve of Papua New Guinea's independence, achieved in 1975, there was much speculation about the future prospects for democracy in this Pacific island state. As an Australian-administered territory, Papua New Guinea had been brought towards independence within a solid Westminster tradition. National elections had been conducted since 1964 (though the early parliaments tended to be dominated by members appointed by the colonial administration); a Papua New Guinean chief minister had led the government since 1972; tentative attempts had been made to foster the growth of political parties; and the traditions of an independent judiciary and a professional public service had been established. In the deliberations which culminated in the presentation of a 'homegrown' draft constitution in 1974, however, a range of institutional options was considered, the Constitutional Planning Committee drawing on a number of constitutional documents, especially those of the post-colonial states in East and West Africa.

In the light of then-recent experiences among the new states of Africa and Asia, and considering the comparatively shallow roots of national political sentiment in Papua New Guinea, particular concerns were expressed about the possibility that, in a post-independence Papua New Guinea state, democracy would yield to either a one-party state or a military takeover.

To counter any tendency towards military intervention, some commentators suggested that specific provisions be made to give the military institutional representation in government (see below). In the event, this suggestion was not taken up, and the military maintained a fairly low profile in post-independence society. But in 1987 political developments in Papua New Guinea and military coups in Fiji prompted some observers to again raise questions about the possibility of military intervention in Papua New Guinea. While a military coup seems to remain a very remote possibility, internal security problems in Papua New Guinea 
over recent years have brought about significant changes in the role of the military and in its relations with government.

\section{The Colonial Heritage}

The Papua New Guinea Defence Force has its origins in the formation, during World War II, of four infantry battalions in the then separate territories of Papua and New Guinea. The four battalions were brought together as the Pacific Islands Regiment (PIR), though all officers and most NCOs were Australian. The PIR fought with distinction alongside Allied troops in Papua New Guinea. It was disbanded in 1946 but was re-formed five years later.

Until well into the 1960s the PIR was essentially a component of the Australian army, and was there primarily to serve Australian defence interests. A former PIR commanding officer, Lt. Colonel Maurie Pears, later wrote, 'We saw PIR as Australia's Ghurka Unit' (Sinclair 1992:153). ${ }^{1}$

During the early 1960s, Indonesia's campaign against the Dutch in what was then Dutch New Guinea (now the Indonesian province of Irian Jaya) and its confrontation with Malaysia sparked fears of possible Indonesian expansionism towards Papua New Guinea, and prompted a surge of activity on Australia's part to expand the military in Papua New Guinea and to strengthen security infrastructure along the Indonesian-Papua New Guinea border. Within the space of a few years the PIR was increased from about 700 'native soldiers' with Australian officers to a force of over 3000. Indigenisation of the officer corps began, the first two officers (Ted Diro and Patterson Lowa) graduating from the Australian Officer Cadet School in Portsea in 1963. A Military Cadet School (to prepare recruits for further training at Portsea) was established in Lae. A water transport base was established in Port Moresby and the wartime naval base on Manus was resuscitated. An Army Aviation Corps was created and several Royal Australian Air Force transport aircraft were posted to Papua New Guinea.

By the mid 1960s, coincident with the perceived threat from Indonesia diminishing, the military build-up levelled off, though Papua New Guinea continued to occupy a significant place in Australian strategic planning. More significant for Papua New Guinea, however, along with the increased expenditure on the military came more serious consideration of the possible future role of a Papua New Guinea defence force. In 1966 the force's incoming commanding officer said:

1 For a detailed history of the PIR, and its involvement in World War II, see Barrett (1969), Mench (1975), and Sinclair (1990, 1992). 
The Army's role in PNG falls basically into two parts - to build an Army capable of playing a major role in the defence of the Territory against external aggression, and to provide for the future a loyal and well-disciplined indigenous force capable of supporting the Government of an independent PNG (quoted in Sinclair 1992:222-23).

In the House of Assembly, at forums at the recently-established University of Papua New Guinea (UPNG), and elsewhere, however, a number of Papua New Guineans expressed apprehension about the growth of a well-provisioned military. In a paper published in 1967, for example, a pseudonymous Papua New Guinean school teacher questioned the Australian government's expenditure on the army, suggesting 'that the army is probably the biggest single threat to the peace, security and development of our country' (Heatu 1967:33; similarly see Warubu 1968; Olewale 1972).

The issue of the military's relations with civil authorities was officially addressed in 1969 by the Australian minister for the Army, Peter Lynch. Lynch described the 'current basic roles' of the army as being to build an efficient force capable of playing a vital part in the defence of Papua New Guinea and to provide a well-disciplined, stable and reliable indigenous force completely loyal to the government (Lynch 1969:22). He went on to say:

Emphasis is placed on loyalty to legally constituted authority. This is implicit in the Australian Government's aim of developing in the Territory a sound political structure in which the Public Service, the [Police] Constabulary and the Army have all been thoroughly trained in the concept of subordination to a legally constituted democratic government (ibid.:23).

To this end the army was involved in a 'heavy education effort', including group discussions of 'civics and christian ethics' (ibid. Also see O'Neill 1971:16-17). Also, although civic action work had been carried out since 1951, from 1967 all major patrols and operational exercises by the PIR included civic action projects designed to "create constructive attitudes in the minds of soldiers towards the people, and help identify the people with their Army' (Lynch 1969:23. Also see Hussey 1968).

Ironically, the success of the civic action program fuelled concerns about the future role of the military in Papua New Guinea. Vincent (Serei) Eri (who later served as defence secretary before becoming governor-general) suggested in 1969 that the army was 'replacing the Administration in the minds of the people' and 'preparing the ground for some future action', and he warned, 'it is a very dangerous situation that we are getting into' (quoted in Sinclair 1992:136). Such concerns appear to have been quite widely shared among educated Papua New 
Guineans, but were countered by army commander Brigadier Hunter, who said,

It is better to have the army out with people, learning to understand them, than to be sitting in their barracks getting big heads. What Papua-New Guinea needs is a people's army, though not in the Maoist form (Canberra Times 23 January 1969).

Not specifically mentioned in Lynch's 1969 statement was the army's possible future role in internal security. This issue was not long in surfacing. Following a disturbance in East New Britain in mid 1970 the Australian government placed the army in readiness to assist the administration should the situation escalate, and troops were given a hastily-arranged course in riot control. In the event the situation was resolved without the army being called in, and there was a general feeling that the administration had acted prematurely. But the events of 1970 clearly signalled a recognition of the broader role the army might be called upon to play in an independent Papua New Guinea, and, along with growing unrest on Bougainville, stimulated further debate.

Australian defence expert Robert O'Neill (1971) suggested that internal law and order was likely to become the army's major preoccupation. Australian journalist Peter Hastings endorsed this view, referring to the 'inescapable similarity between Africa and Papua New Guinea', and suggesting that after independence 'the Army will inevitably be involved in the political direction of the country' (Hastings 1971:32). The future role of the army was also the subject of a local radio program, ${ }^{2}$ which brought together defence force personnel, politicians, and civilian commentators. Papua New Guinea's newly-elected chief minister, Michael Somare, expressed the view that 'we do probably need a defence force' - for patrolling borders and territorial waters, and 'to react in the first instance to any armed aggression' - but he suggested that it should be of a smaller size and that it should only be involved in internal security operations in 'a real national emergency'. As against this, senior Papua New Guinean officer, Major Ted Diro, saw the army as having a role to play in internal security matters, and UPNG lecturer Ulf Sundhaussen argued that given the very low level of national consciousness and 'already surfacing tendencies for separatism' the maintenance of internal security would be a task for the army in Papua New Guinea, as it was in Asia and Africa, and that the army should have 'some sort of political say'. Sundhaussen (who had studied the military's role in Indonesia) advocated the development of working relationships between officers and politicians and the integration of the military into the political and social structure. At this time there was some debate

2 'The Sword and the State'. Two-part program by Australian Broadcasting Commission, 2, 9 November 1972. 
over Sundhaussen's suggestion that the military be represented in cabinet (see, for example, Sundhaussen 1973a, 1973b; Mench 1975: chapter 5, and Premdas's 1974 critique of Sundhaussen), and there were proposals, supported by Australian External Territories Minister Morrison, to combine the army and police in a paramilitary force (Morrison advocated a Malaysian-style field force). But when in 1974 the Constitutional Planning Committee (CPC) presented its report, its recommendations followed the approach outlined earlier by Somare.

The CPC began by emphasising its belief in the general principle, 'that the disciplined forces should at all times be subject to the control of the elected government' (CPC 1974:13/1). It went on to express the view that the Defence Force should be 'firmly oriented towards external defence' (ibid.:13/3):

... we have very serious reservations about the possibility of a future Papua New

Guinea Government using the army against its own people in any but the most ex-

treme cases of civil disorder, and then subject also to specific conditions (ibid.).

Its reservations on this issue were reinforced by concerns about what it saw as the provision of installations and equipment 'at a standard that has little relevance to the circumstances of Papua New Guinea' and about 'the elitist nature of the Defence Force' (ibid.). It consequently recommended an expansion of the police force and the appointment of a commission of inquiry to recommend on the relative size of, and allocation of resources between, the police and the military.

With minor modifications, the CPC's recommendations on the disciplined forces were accepted by parliament and were written into the constitution of the independent state (see May 1993:10-13). The supremacy of the civilian authority is laid down in Section 201, which states that the force is subject to the 'superintendence and control' of the National Executive Council (NEC) through the minister responsible for the defence force (who may not be a serving member of the force). Contrary to the CPC's recommendation, the constitution specifically excluded the office of commander-in-chief. The question of the relative size of the police and the army was not taken up, the level of military expenditure being effectively underwritten by an Australian military assistance program.

In 1973 the former PIR was redesignated Papua New Guinea Defence Force (PNGDF) and shortly before independence the formal transfer of defence powers took place. Brigadier-General Diro became the PNGDF's first Papua New Guinean commander.

\section{The Role of the Military in Post-Independence Papua New Guinea}

Papua New Guinea had an easy transition to independence in 1975. Indeed it has frequently been observed that the absence of a significant anti-colonial 
nationalist struggle in Papua New Guinea not only meant that Papua New Guinean soldiers had no heroic role to play in the winning of independence but that the new state was deprived of the unifying forces which such struggles were seen to have provided in many post-colonial societies.

The government which emerged from pre-self-government elections in 1972, under the leadership of Michael Somare, was a coalition government, and in the first post-independence elections in 1977 it was returned to power. Since then there have been three national elections and five changes of government. All changes of government have taken place through normal constitutional channels (three as the result of votes of no confidence and two through elections) and all have been smooth transitions. All governments have been rather fluid coalitions. The two-party Westminster-style politics envisioned by some in the 1970s has not materialised; but neither has a tendency to one-party or military regime. Papua New Guinea remains a robustly competitive political system. Separatist movements which emerged on the eve of independence, and resulted in unilateral declarations of independence in Papua and in the North Solomons (Bougainville) (Griffin 1976; May 1982) were dealt with by a combination of disregard and political negotiation. That in the North Solomons (where disputes had arisen over a large gold and copper mine) precipitated moves for political decentralisation. Following the establishment of provincial governments and the renegotiation of the Bougainville mining agreement this problem seemed to have been solved.

Preoccupied with the problems of policy making in the new state, and facing no serious external threat, Papua New Guineans were not greatly concerned about the role of the army, which maintained a fairly low profile. It was not until the 1980s, with a progressive breakdown in law and order nationally and the reemergence of friction on Bougainville, that the role of the PNGDF again came under serious scrutiny.

At the time of the transfer of defence powers in 1975, the PNGDF had a posted strength of 3614, 14 per cent of whom were Australians, mostly officers and specialist NCOs. Less than 35 per cent of the 375 officer positions had been localised. By 1979 the number of loan personnel had fallen to 141 and by 1988 to 30, most of whom were with the Air transport Squadron. There were by 1979 almost 300 Papua New Guinean officers. Since independence, military assistance to Papua New Guinea has been provided through the Australian Defence Cooperation Program (DCP). In 1991 Australian Defence sources estimated that some 3000 PNGDF personnel had undertaken some form of training in Australia since 1975, and that about 90 per cent of the officer corps had trained or studied in Australia (JCFADT 1991:174 and JCFADT, Hearings, 22 October 1990, 
p.733). Additional assistance has been received from the US and New Zealand, and in 1992 Papua New Guinea signed status of forces agreements with Indonesia and Malaysia; Defence Secretary Peipul said, 'We may be able to learn from Malaysia on handling domestic security and from Indonesia on civic action'. ${ }^{3}$

Notwithstanding the high level of Australian assistance under the DCP, as early as 1977-78 the Defence Report contained complaints about deficiencies in the size and structure of the PNGDF. The Defence Report 1980 commented that with its present budgetary allocation the PNGDF could not meaningfully achieve its primary object of defending the country from external attack. In 1983 a defence policy review recommended that the PNGDF's force strength be reduced to 3050 . The proposed cut was bitterly received in defence circles, where morale was said to be low. In 1984 a Defence manpower review revealed a wastage rate among officers of 7.7 per cent and among other ranks of 15.8 per cent (Defence Report 1984-85:44), and the Defence Report 1984-85 reported that the standard of discipline during 1985 was 'below the required standard' (ibid.:39). This growing frustration within the PNGDF coincided with demands for increased operations on the Irian Jaya border and the first call-out of the PNGDF to assist police in 1984. In 1988 the annual Defence Report noted that most operational units were 70 per cent below strength and that the PNGDF was having difficulty retaining specialists. That year, however, a Defence Policy Paper outlined proposals for a ten-year program to replace major equipment, reorganise force structure and enhance capabilities in several areas. (See also Defence Report 1988.) Although cabinet approval for the PNGDF's Ten-Year Development Plan did not come until late 1991, after the government had undertaken a review of internal security, several policy changes were initiated in 1988-89, against the background of the emerging conflict between the security forces and rebels on Bougainville (see below). These included decisions to increase the strength of the Force to 5200 by 1995 , and to proceed with plans (approved in 1985) for the development of a reserve force.

By 1992 force strength had risen to around 4200. But in presenting the 1993 budget, the minister for Finance announced new strategies in the law and order sector, which recognised 'that there are limitations on the ability of the agencies concerned to control the current situation' (1993 Budget Documents. Volume I. Economic and Development Policies, p.122). With respect to the PNGDF:

... it is recognised that the Defence Force needs to be scaled down, become more involved in civic action, more involved with the village and community, more co- 
ordinated with other agencies in both the law and order and other sectors, and better disciplined' (ibid.).

The 'move into Civic Action' was to be accompanied by a reduction in force strength, through attrition, from 4200 to 2500-3000, 'most of whom will perform CAP activities at the village level'; a core group of 1000 to 1500 'will receive specialised combat training to prepare them to effectively counter any major internal threat' (ibid.).

Towards the end of 1993 the PNGDF faced a financial crisis. For several years defence spending had been substantially in excess of budget allocation (in 1991 defence spending was overbudgetted by an extraordinary 81 per cent). By 1993 , outstanding accounts with local suppliers and unpaid special allowances to defence force personnel amounted to several million kina, and in September it was announced that naval and air craft could not be used because of a lack of funding. In Port Moresby soldiers returning from Bougainville attacked the pay office when they failed to receive due pay and allowances. The government responded by increasing the Defence budget.

As of 1994, it remains to be seen how the conflicting pressures, on the one hand for an enlarged, better-equipped fighting force and on the other for a reduced civic-action oriented force, will be resolved.

In the period leading up to independence the possibility of ethnic fragmentation was a major concern both of the Australian administration and of the rising nationalist politicians. The emergence of a number of subnationalist or 'micronationalist' movements in the late 1960s and early 1970s exacerbated these fears (see May 1982). Recognising this (and bearing in mind that ethnic tensions had been a reason for the disbanding of the PIR in 1946), as early as 1951 the army's recruiting policy was carefully designed to achieve a regional balance. Initially the PIR sought to recruit equal numbers from Papua, the New Guinea islands, and the New Guinea mainland; but with the highlands closed to labour recruitment and difficulties of reaching more remote areas, in fact recruitment was biased towards the groups closest to Port Moresby, Lae and Rabaul. In 1967 an Australian officer serving with PIR, noted that 'Mutual suspicion remained high and clashes between tribal factions could, and did, flare up at any time' (Bell 1967:50).

The expansion of the PIR in 1963-65 gave the army the opportunity to achieve a better regional balance, although the fact that the army now sought higher education levels, for technical and officer training, meant that some coastal groups were still overrepresented. Thus, five of the first six officers commissioned were from the Rigo district of Central Province, and NCO ranks were said to be dominated by 'Bukas' from the North Solomons. 
Initial fears of an ethnically divided army seem to have fairly quickly dissipated. In fact, Bell observed in 1967 that with the new generation of 1960s recruits came a breakdown of 'tribal loyalty' and a rise in Papua New Guinea nationalism, even though some 'inter-tribal prejudices' remained (Bell 1967:56). The achievement of integration in the PIR - the creation of what Olewale (1972:223) described as 'a sort of super-tribe' - did not go unnoticed among those apprehensive about the future role of the military, who saw the unity of the army in an emerging state characterised by fissiparous tendencies as a potential threat to democratic rule (for example, see Hastings 1971).

An official policy of recruiting 'from each region to maintain a reasonable balance within the Force vis-à-vis the population distribution throughout PNG' (Defence Report 1977-78:32) has been maintained since the 1960s. However the analysis of figures of force strength by rank and province (see May 1993:28) suggests that regional representation is by no means balanced. In particular, it shows a marked 'underrepresentation' of the populous highlands provinces, particularly at senior officer level, and a significant 'overrepresentation' of coastal Papuans and New Guinean islanders at senior levels.

In the latter part of the 1980s there was a hint of regionalism in rumours of collaboration between some Papuan colonels and PNGDF-commander-turnedpolitician Ted Diro, and regional sentiment was certainly evident in reaction outside the Force to the sacking of Nuia and three other Papuan colonels (see below); however this does not appear to have reflected any basic ethnic division with the Force.

In the early discussion of the role to be played by a defence force in independent Papua New Guinea, primary emphasis was placed on its function of defence against external threat. There was ambivalence about its possible use in maintaining internal security. As early as 1971, in the wake of increasing lawlessness in the highlands, highlands politicians called for the use of the PIR 'for security purposes' and supported proposals for the secondment of PIR officers to train police, particularly police riot squads. There was initial opposition to this but in 1973 four Australian Army officers were seconded to assist in training and administration; three of them were posted to riot squads.

As the general law and order situation in the country deteriorated, and particularly after the declaration of a state of emergency in the five highlands provinces in 1979, opposition to the use of the army for internal security purposes diminished. From 1977 there were calls for the deployment of the PNGDF to assist police in dealing with tribal fighting and criminal activity in the highlands. The first actual call-out in aid of the civilian authority, however, did not occur until 1984. 


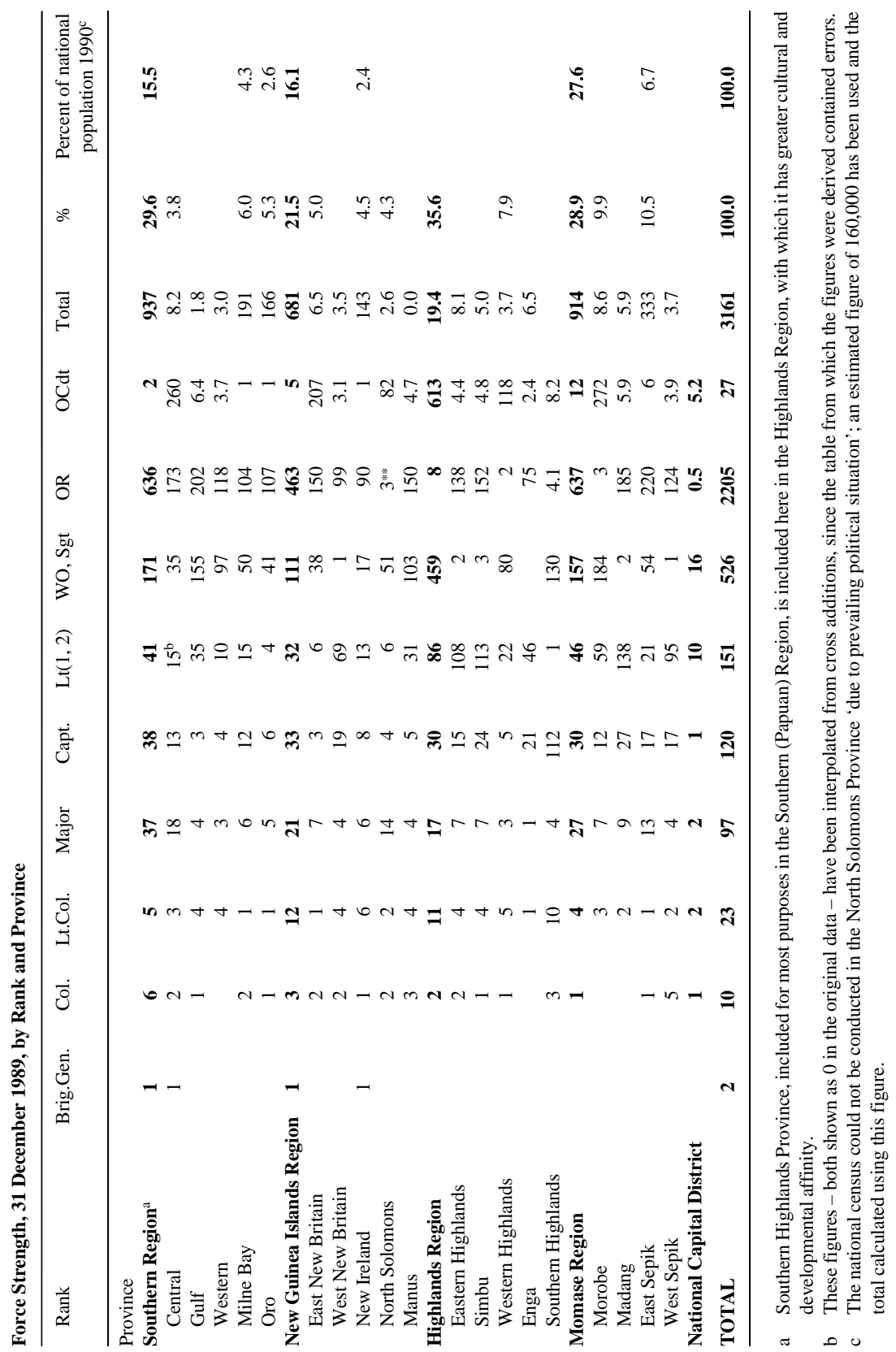


In 1984 the government announced a list of measures to deal with law and order problems, including call-out of PNGDF personnel to assist police. Diro, by then a member of parliament, supported the use of troops. At the end of that year the PNGDF was called out to assist police following the declaration of a state of emergency occasioned by rising urban crime and violence in Port Moresby. 'Operation Green Beret', as the exercise was called, lasted for about four months and was generally regarded as a success, though the urban crime rate quickly rose again when the state of emergency ended, and two months later the troops were called out again in the National Capital District, in an operation which lasted five months.

On several occasions in the early 1980s there were demands from national politicians to use the PNGDF to quell tribal fighting, particularly in Enga Province. In a Post-Courier article in 1985 former PNGDF officer Ian Glanville opposed such suggestions, arguing

To have a disciplined, armed and trained Papua New Guinean in uniform, shooting other Papua New Guineans in a situation other than where 'the national security or the preservation of public order exists' $[$ sic $]$ will forfeit any claim we might have to being a Christian, democratic, and enlightened country, and destroy forever our fragile national unity (Post-Courier 10 December 1985).

However, in 1987 the PNGDF was called out to assist police in law and order operations in Morobe, Madang and Eastern Highlands provinces, and the following year was mobilised to assist in 'Operation LOMET 88' in the highlands provinces, Morobe and Madang, and later East Sepik. LOMET 88 lasted for over three months and it attracted a great deal of publicity (see below); but the PNGDF's role in it, though conspicuous, was limited - of 519 security forces personnel involved (including 308 from the Police Mobile Squad) only 33 were from the PNGDF (Draft Hansard 10 November 1988, p.28). Late in 1988 there was a further request, from the Morobe provincial law and order committee for PNGDF assistance to counter serious crime in Lae and Garaina (Post-Courier 20 December 1988). But by this time the Force was on standby awaiting a government decision on whether it was to be called out to assist the police on Bougainville. (The subsequent role of the PNGDF in the Bougainville crisis is discussed in more detail below.) PNGDF personnel were used again 1991 to provide additional security during the South Pacific Games in Port Moresby and to assist police in 'crime busting operations' in Morobe Province.

In 1992 it was something of a measure of the extent to which the army had come to be accepted as having a 'law and order' role that in outlining arrange- 
ments for the conduct of the national election is was said to be "necessary to call upon the services of the Defence Force ... to assist the Electoral Commissioner before, during and after the election' (Post-Courier 24 March 1992). On the eve of the elections some 1300 police and 50 soldiers paraded through Mount Hagen in a display of force.

Despite the general acceptance of the PNGDF's role in internal security situations, however, the acceptance was slow to be recognised in official statements. In 1984, shortly before the first call-out of the PNGDF to aid the civil authority, the NEC's list of priority functions put internal security last. The Defence Report 1984-85 (p.54), however, stated that 'national security and development was foremost in our activities'. In 1987, in a statement delivered on resigning from cabinet (see below), Diro said

Clearly a military option for the defence of Papua New Guinea is out. The Defence Force must now be tailored to give priority to training in low intensity type of operations, civil aid tasks, internal security problems, rapid deployment to assist police or in instances of hijacking and of course surveillance of both land and sea boundaries (Times of PNG 19-25 November 1987).

The following year Defence Secretary Mokis told an Australian seminar that his department's view was that 'there is a far greater prospect of PNG being troubled seriously by internal rather than external security problems'; he saw the main challenges coming not from tribal fighting or separatism but from increasing criminal activities:

... concentrations of unemployed people, many of whom are young and smarting from unfulfilled expectations, have provided a fertile breeding ground for criminal activities. These trends have coincided with a general decline in the efficiency of PNG administration and, perhaps most notably in this context, a significant weakening of the system of justice; the police, the courts and the gaols. Other potential sources of internal security, such as tribal fighting and separatism, have caused difficulties in the past but at present seem of far less concern (Mokis 1988:2).

Yet in 1989, having noted the PNGDF's responsibility for defending the nation from 'external threats and internal uprisings', the Defence minister went on to say that 'internal uprising and internal security [was] the responsibility of the Royal Papua New Guinea Constabulary' (Defence Report 1989).

In 1990, facing an escalating law and order problem across the country, and with a crisis in Bougainville still unresolved, the Namaliu government set up a Security Review Task Force and, shortly after, convened a National Summit on Crime. As an outcome of these initiatives it released a report (PNG 1991) in 
which it was observed that 'perceived political instability...is sometimes thought to have given rise to public questioning of the durability of particular leaders, policies and even laws', and that the disciplined services had not been able to cope with 'sources of law-breaking and disorder' (ibid.:11, 17, unnumbered). It also referred to 'the growing frequency with which call-outs of the PNGDF in aid to the civil power and states of emergency have been declared' (ibid.:24). Among a number of recommendations the report proposed the establishment of a Joint Services Command Centre and the progressive integration of the disciplined forces ('subject to review and even possible reversal') (ibid.:23-30). It also suggested that 'the most serious, foreseeable threats facing Papua New Guinea are internal' and that the priorities of the PNGDF 'should be reviewed and, as may be appropriate, re-ordered' (ibid.:36). The demand for a change of focus was supported by Defence Minister Benais Sabumei, who in 1991 told a PNGDF passing out parade that 'The real future of our Defence Force is to assist the civil authorities deal effectively with these threats' (Post-Courier 2 July 1991).

Coincidentally with the Papua New Guinea government's security review, the Australian government undertook a review of its security assistance programs for Papua New Guinea, and in September 1991 the two governments released a statement which announced that Papua New Guinea was to give highest priority to internal security needs, and that Australian assistance would be geared to supporting Papua New Guinea's disciplined forces in maintaining internal security, including law and order. This was to be done by way of training and the provision and funding of infrastructure, equipment and other support facilities. But it is notable that, following well-publicised reports of abuses by Papua New Guinea's security forces on Bougainville, an Australian government document described Australia's military training efforts as having several components 'designed to strengthen soldiers' awareness of humanitarian law to provide guidance concerning proper treatment of civilians during security operations'. Operational training, it said, was 'based on Australian Defence Force doctrine, which in turn draws on the Geneva Convention' (Evans 1992:34-35).

Thus within sixteen years of independence the priorities of the PNGDF had been effectively reversed and the possibility of an integrated paramilitary force revived, though to date there has been no move to implement the latter proposal, which remains unpopular among both RPNGC and PNGDF personnel.

\section{Military-Civil Relations in the Independent State}

From a very early stage, the Australian officers responsible for the training of 
Papua New Guinean soldiers were anxious to instil in their protégés the idea of the subservience of the military to the civil authority, and to ensure that relations between the military and politicians were cordial.

The achievement of cordial civil-military relations should have been rendered easier in post-independence Papua New Guinea by the fact that, given the nature of pre-colonial Papua New Guinean societies (for the most part small and nonhierarchical) and the recency of effective colonial administration in much of the country, defence force personnel and the emerging nationalist politicians and civil servants came from similar village backgrounds, and in the case of the bettereducated had been to the same government-run schools in much the same age cohort. The PNGDF's first Papua New Guinean commander, Ted Diro, for example, came from a village in the Rigo district, where his father had been a plantation labourer and a carrier for the Allied troops during World War II. In common with the other two young men selected for early officer training, and with many of the leading politicians and civil servants of the late 1960s and 1970s, Diro had attended the government high school at Sogeri. But perhaps because of the military ethos inherited from the colonial period, and the nature of the military training, relations between senior military officers on the one hand, and politicians and public servants on the other, were not particularly close; indeed Sinclair (1992:297) describes relations in the early 1970s as 'frosty' (also see O'Neill 1971; Sundhaussen 1973b). Politicians tended to see the military as elitist and a possible threat to civilian rule, and the military had misgivings about politicians who questioned the future role of the defence force and suggested that it might be too big.

Despite this degree of separation of military and civilian circles, within the first few years of independence there were suggestions that the higher echelons of the military were being politicised.

Diro and Lowa had been rivals for the top position during their early military careers and on the eve of independence, as it became clear that Diro was the likely choice for commander, Lowa resigned and joined Prime Minister Somare's office. He subsequently contested the national elections in 1977 as a Pangu candidate, was elected to a seat in Port Moresby, and became minister for Police in the second Somare government. In the following months there were rumours that within the Somare government there were moves to oust both General Diro and the police commissioner, Pious Kerepia, both of whom were felt to be 'politically unreliable'. Lowa was said to be prominent in these moves. In November, following a series of disputes among senior police officers, Kerepia's tenure was terminated, though he protested, alleging political interference. The same month a challenge to Lowa's residential eligibility was upheld and he lost his parliamen- 
tary seat. (Lowa later became national organiser of the Melanesian Alliance party and was re-elected to parliament in 1987.)

Meanwhile, tensions in the relations between members of the government and senior PNGDF officers came to a head in what was termed 'the Diro affair'. During 1977 Diro had held discussions with a leader of the West Papuan separatist movement, Organisasi Papua Merdeka (OPM). Although Diro claimed that the Defence minister had been fully briefed on the talks, there was a feeling in cabinet that Diro had exceeded his authority and in late September it was announced that he would be officially reprimanded. The reprimand came a week later. By this time Diro had sought and received a commitment of support from senior officers, and there were rumours in Port Moresby of a possible coup (see SMH 6 October 1977; Hegarty 1978:402). At the time Diro told cabinet:

... I have now been able to assess who my friends are and who aren't ... Mr Prime Minister, I want you to know that the force is becoming sick to death of being made a political football by certain politicians and ex-politicians (quoted, SMH 6 October 1977).

Though one commentator described the incident at the time as 'the most serious threat to the authority of the government since independence' (Hegarty 1978:402), it appeared to blow over fairly quietly. Six years later, however, an anonymous former PNGDF officer ${ }^{4}$ told an Australian Broadcasting Commission correspondent ${ }^{5}$ that had Diro been sacked in 1977 PNGDF officers would have staged an already-rehearsed operation, codenamed 'Electric Shock', in which the prime minister and certain other politicians and public servants would have been taken hostage. The former officer claimed that PNGDF officers had been in contact with the Indonesian government during this period; indeed one of their major concerns had been the Papua New Guinea government's poor handling of the border situation. Diro's role in all this was unclear and the story was denied in some quarters (see Times of Papua New Guinea 26 August, 15 September, 7 October 1983); certainly it may have been embellished by 1983. But it served as a reminder that military intervention was not an impossibility.

Four years after the 1977 incident, Diro announced that he was resigning from the PNGDF to contest the 1982 national elections. He stood as leader of a (mostly Papuan) PNG Independent Group and was elected. In the process of coalition

$4 \quad$ The former officer was Tom Poang, a colonel and chief of personnel at the time, who left the PNGDF soon after and in 1983 was speaker in the Morobe provincial assembly.

5 Geoff Heriot, ABC ‘Background Briefing’ 21 August 1983. 
formation the ambitious Diro was at one stage tipped as possible prime minister, but he ended up in opposition, briefly accepting leadership of the National Party, and becoming minister for Forests in 1985 when a vote of no confidence brought a change of government.

Diro was not the only former PNGDF officer to contest the 1982 elections: in Manus, James Pokasui, who had been transferred to Manus the previous year as adjutant of the Maritime Element, stood as an Independent Group candidate and was initially declared winner, though the result was subsequently overturned by the Court of Disputed Returns, ${ }^{6}$ in Wewak, former PNGDF major Michael Malenki, who had left the PNGDF in 1977 to become electoral secretary to Prime Minister Somare but had fallen out with Somare and became national secretary of the Melanesian Alliance, stood unsuccessfully (he was later elected to the East Sepik Provincial Assembly).

With Diro's resignation from the PNGDF it was generally expected that Colonel Ken Noga, who had been the third most senior Papua New Guinean officer after Diro and Lowa, would succeed him. Instead, the position was given to Colonel Gago Mamae. In 1980 a split in the ruling Pangu-led coalition and a subsequent vote of no confidence against Prime Minister Somare had brought a new coalition government to power, headed by Somare's former deputy prime minister, People's Progress Party (PPP) leader Sir Julius Chan. In 1977 Noga had resigned from the PNGDF to contest the national elections as a pro-Pangu candidate, having rejoined the force when he failed to be elected. ${ }^{7}$ Some suggested that Mamae had been appointed over Noga in 1981 for political reasons. The suggestion that political considerations had entered into the selection of the PNGDF command was reinforced in 1983 when, having been reelected to office in the national election of the previous year, the Somare government replaced Mamae with Noga as commander of the PNGDF. A newspaper editorial at the time asked: 'Must we continue to entertain political appointments in the public service ...?' (Times of PNG 26 August 1983). Mamae, after serving for a while as military attaché in Australia, resigned and became executive officer in Chan's PPP office (standing unsuccessfully as a PPP candidate in the 1987 national elections).

The politicisation of the senior PNGDF appointment was demonstrated even

6 Pokasui subsequently worked for Fr John Momis, parliamentary leader of the Melanesian Alliance, and was elected in 1987, becoming minister for Defence.

7 Under the provisions of the Defence Act 1974 it is possible for a member of the PNGDF to transfer to the reserve force, and later apply for re-admission to the regular force. 
more blatantly three years later, when another vote of no confidence again removed a Somare-led coalition and brought to office a government headed by Paias Wingti and Julius Chan. Noga was himself removed and replaced by Colonel Tony Huai. Huai had been in consideration for the top position in 1982. In 1984 he resigned, criticising the government's handling of the PNGDF. He initially joined Mamae in Chan's PPP office and indicated his intention of standing for parliament in 1987. At the time of his appointment Huai was a security officer with Air Niugini and the appointment of a commander from outside the PNGDF was reportedly opposed by the Defence Department and resented by some senior officers. Opposition leader Somare described it, not without irony, as a 'dangerous precedent' (Post-Courier 3 December 1985).

Huai proved to be a controversial figure as PNGDF commander. Early in 1986, on his return from a visit to Indonesia, Huai told a press conference that he would closely cooperate with Indonesian army forces commander, General Benny Murdani, to stamp out the OPM. His statement attracted criticism, notably from prominent lawyer (later Justice minister) Bernard Narokobi, who said that Huai had no authority to make public statements about matters of defence policy, and called for his dismissal. Huai resigned in late 1986 but was reinstated. The following year Huai again attracted public attention when it was reported that, having been opposed to the defence provisions of the Joint Declaration of Principles then being negotiated between Papua New Guinea and Australia, on the grounds that a reference to possible 'attack from an external source' could be misread by Indonesia and create unnecessary tension, Huai had made unauthorised visits to Indonesia and had leaked details of the progress of discussions to General Murdani (see Times of PNG 4-10 February 1988). He was also said to have accepted gifts of uniforms and furniture from the Indonesian army chief. According to a Times of PNG report (24 December 1987-7 January 1988), Huai's close relations with Murdani had nearly resulted in a mutiny by senior officers and NCOs. Partly as a result of this, but also, according to Defence Minister Pokasui, because Huai had allowed infighting and political lobbying among senior officers, Huai was dismissed in late 1987. He was replaced by Colonel Rochus Lokinap. Lokinap was the first non-Papuan commander of the PNGDF, coincidentally coming from a village in Sir Julius Chan's New Ireland electorate.

By this time, too, Diro's political fortunes had begun to turn. Having been reelected in 1987 Diro managed to swing the entire bloc of members from Papuan electorates into a coalition with Paias Wingti, thus delivering government to Wingti when it looked as though a Pangu-led coalition would be returned to power. He became deputy prime minister in the new government. However, an enquiry set up by Wingti in 1987 to investigate allegations of corruption in the 
forestry industry had accused Diro of involvement in a number of illicit transactions and recommended prosecution. Further, in the process of investigation it was revealed that Diro had received from Indonesia's General Murdani some \$US139400, ostensibly as a contribution to his 1987 election campaign expenses. This 'contribution', which had not been declared, was in defiance of a provision of the Papua New Guinea constitution which states that an organic law will be passed to prevent candidates or parties accepting contributions from foreigners (though in fact the organic law had never been passed).

Charged with perjury and facing possible prosecution, and with calls for his resignation from parliament, Diro resigned from cabinet. In subsequent statements to the press he said:

... the events of the past couple of months have had implications leading to rumours of disobedience in the disciplined forces... I have been one of the experts on military coups through the world [and] ... the ingredients are here for a coup ... I do not want to be blamed when that arises. (Post-Courier 9, 16 November 1987; Times of PNG 19-25 November 1987).

In the wake of the military coups in Fiji in 1987 - the first in the island Pacific and generally unexpected - such comments were not dismissed lightly. With rumours circulating in Port Moresby about an impending coup (Saffu 1988:25960), three senior colonels (Kwago Guria, Lima Dotaona and Robert Dademo), all of them Papuans, were removed, although the possible links between the talk of coups and the government's actions were never made clear. This action was bitterly criticised within the Papuan community, especially from within the thenrecently-formed People's Action Party (PAP), a predominantly Papuan group of which Diro was parliamentary leader. Following a change of government in 1988, the three were reinstated (though Guria chose not to return).

Shortly after resigning from cabinet, Diro shifted the parliamentary allegiance of his bloc and in so doing brought about a change of government. He became minister of state in the new (Namaliu) government and having been acquitted of the perjury charges subsequently became deputy prime minister. But in 1991 he was found guilty by the Leadership Tribunal of eighty-one counts of misconduct and was forced to resign from parliament. This threatened to precipitate a constitutional crisis when the governor-general, Sir Serei Eri, formerly president of Diro's PAP, refused to sign the dismissal papers and attempted to reinstate Diro as deputy prime minister. Eventually both Diro and Eri resigned. Ironically, remembering the events of 1977, the PNGDF was placed on alert at the time 'in case of violence between ethnic groups' (Times of PNG 3 October 1991).

The following year, after another, Wingti-led, coalition had come to office fol- 
lowing national elections, there was a further major reshuffle within the PNGDF. In November 1992 Lokinap's extended term as commander came to an end; criticised for his handling of the Bougainville situation, he was not reappointed. In his place Colonel Robert Dademo, one of the Force's longest-serving officers (and one of the three Papuan officers dismissed under a previous Wingti government) was appointed as Brigadier General. Dademo was generally regarded as a sound choice, though some claimed that his appointment was 'political'.

Soon after his appointment, a leaked document claimed that Dademo had recommended that five senior officers be replaced, but had been overrruled by Defence Minister Tohian. Subsequently, while Tohian was in Australia, the NEC approved the transfer of the five officers (one was posted to Indonesia, one to Australia, one to New Zealand, and two to other government departments); four officers were promoted to colonel to fill vacant positions. A Times of Papua New Guinea report (30 December 1992) said the moves 'strengthen the commander's position enormously and remove a number of his former rivals from key jobs in the force'.

In early 1994 Dademo reached retirement age and, in the absence of Prime Minister Wingti, Chan as acting prime minister announced the appointment, as acting commander, of Colonel Lima Dotaona. On his return a day later, however, Wingti overruled his deputy prime minister and Defence minister; the Defence Retirement Regulations were amended to raise the retirement age and Dademo's appointment was, controversially, extended.

With the politicisation of senior levels of the PNGDF and increasing pressures, budgetary and operational, upon the military, came also suggestions of declining morale and deteriorating discipline in the force.

As early as 1985 the standard of discipline in the PNGDF was said to be 'below that required' (Defence Report 1984-85: 39, 44) and a concentrated effort was made 'to purge the force of soldiers whose service was considered unsatisfactory'; 190 'other ranks' were discharged. The same year some forty Air Transport Squadron groundcrew were accused of 'mutiny' when they staged a strike over pay and conditions.

More serious allegations of undisciplined behaviour by the security forces arose during Operation LOMET in the highlands in 1988. Foreshadowing later developments on Bougainville, there were widespread reports of village houses, stores and community centres being burned, of pigs and cassowaries being shot, of looting, and of village people being beaten and raped (Draft Hansard 11 November 1988 pp.10-11, 18 November 1988 pp.16-17; Post-Courier 20 October 1988, 15, 17, 18 November 1988). Much of the blame was attributed to the Police Mobile Squad, which already in the mid 1970s had acquired a bad 
reputation in the highlands, but PNGDF personnel were also accused of offences and there were calls for its withdrawal from such operations. (Nevertheless, four years later Standish [personal communication 1992] reported similar abusive behaviour by police and PNGDF soldiers in the highlands during the 1992 elections.)

In 1988-89 problems of discipline were manifested on a larger scale in open challenges to the government's authority by elements of the military. In June 1988, the minister for Civil Aviation announced a decision to close Lae airport (it had been decided, in accordance with a recommendation of the 1983 Defence review, to relocate the airport some 40 kilometres outside Lae at an old wartime strip at Nadzab). The PNGDF, whose air element had opposed the move, responded by flying personnel from Port Moresby to Lae to 'secure the airport' against Civil Aviation authorities. Lokinap subsequently announced that all Defence Force planes would be grounded. Several days later, having been severely reprimanded by Prime Minister Wingti, Brigadier Lokinap apologised for the PNGDF's actions and assured the prime minister and the people of Papua New Guinea of the PNGDF's undivided loyalty. Nevertheless the Defence Report 1988 (pp.5, 13) listed amongst the year's military operations: 'Operation Albatross'. This operation secured the Lae City airfield and prevented its destruction by elements of the Department of Lands and Department of Civil Aviation'.

Then in early 1989, angered at not having received expected pay increases (the first since independence), some 300-400 soldiers marched on the National Parliament, where windows were smashed, vehicles overturned, and civilians and politicians abused. There was also a smaller demonstration by PNGDF personnel in Wewak. The government promptly suspended the commander, chief of staff, and secretary for Defence, and set up a Defence General Board of Inquiry to investigate the incident. But the government quickly implemented pay increases, and while the Board of Inquiry noted a serious decline in discipline ('There is an apparent inability and or reluctance by commands at all levels to impose discipline' - Report p.49) and evidence of some misuse of funds and equipment, its report was largely devoted to discussing problems of morale and recommending improvements in conditions of service within the PNGDF. While the board's analysis may have been accurate, it did little to reassure the public or political leaders.

Further incidents during the early 1990s (including a strike by maritime and air element personnel in 1994) suggested that, notwithstanding action taken after the 1989 review, problems of discipline remained (see May 1993:55-56).

Overarching all these incidents, however, from 1988 was the much larger issue of the performance of the security forces on Bougainville. 
In 1988, simmering discontent within the landowner group around Papua New Guinea's immense gold and copper mine on Bougainville erupted into a major confrontation. ${ }^{8}$ Mine installations were subjected to a series of arson and sabotage attacks, during which pylons carrying power lines to the mine and town at Panguna were blown up, and workers attempting to repair lines were threatened by armed men. (Among the leadership of the militant landowner group was a former PNGDF officer trained in the use of explosives.) Late in 1988 the mine operator, Bougainville Copper Ltd (BCL), temporarily closed the mine and a government committee attempted to negotiate a settlement with the dissident group. But following further acts of sabotage against BCL installations and government property, police reinforcements were called in and a curfew was imposed in the mine area. Shortly after this riots broke out in the nearby town of Arawa after a series of incidents, not directly related to the mine dispute, in which three people were killed. With tension rising and longstanding separatist sentiments regaining strength, the curfew was reimposed and PNGDF troops (whose call-out had been authorised in December 1988) were brought in to assist police restore law and order. By March 1989 there were approximately 600 police and military personnel on Bougainville, under the direction of a joint planning committee headed by the provincial administrative secretary. Within weeks of its arrival the PNGDF had suffered its first casualties when a PNGDF patrol was ambushed, and it was reported that the PNGDF had launched a 'full-scale military operation' against 'the rebels'. Shortly after, dissident leader Francis Ona announced a revised set of demands against the mining company and the government, which, apart from massive financial compensation, included a call for the withdrawal of all security forces. 'We are not part of your country any more,' he told the government, 'We belong to the Republic of Bougainville' (Niugini Nius 12 April 1989). Premier Joseph Kabui described the situation as serious: the issue was no longer merely about land, he said, but also involved the question of secession (Post-Courier 23 May 1989).

After further attacks on the mine had forced its closure, the government announced tighter security measures, including wider powers for the police and army under an amended Defence (Aid to Civil Power) Regulation. However, the government wanted to avoid at all costs a military operation, Prime Minister

8 For a more detailed account of the background to the 'Bougainville crisis', the ongoing events, and their broader implications, see May (1990), May and Spriggs (1990), Oliver (1991), Spriggs and Denoon (1992), Liria (1993) and The Contemporary Pacific 4(2), 1992, special issue, 'A legacy of development: three years of crisis in Bougainville'. 
Namaliu said, and was not entertaining the possibility of military action 'at this point' (Canberra Times 26, 27 May 1989). But when talks failed, Namaliu ordered an all-out attack on the rebels, who were now calling themselves the Bougainville Revolutionary Army (BRA).

The government's repeated attempts to negotiate with Ona were seen by some, both within and outside the security forces, as a sign of weakness on the part of the government. Police Commissioner Paul Tohian was reported to have complained of 'political interference with essential police work and political indecision', and to have threatened to defy government directives in his attempts to capture Francis Ona. When, in response, prominent Bougainvillean politician and minister for Provincial Affairs, Fr John Momis, criticised Tohian and threatened to move for his dismissal, a group of about one hundred angry policemen marched on Momis's home and warned him against sacking the commissioner. Shortly after this, the acting PNGDF chief of staff, Colonel Leo Nuia, publicly rebuked the Defence minister, saying he 'should refrain from making wild statements on matters affecting the operations of the soldiers and police' on Bougainville (Niugini Nius 12 April 1989). The acting commander and the chief of PNGDF operations on Bougainville also publicly criticised the government's handling of the crisis. Within the PNGDF and RPNGC there were many who felt that they could 'clean up' the situation on Bougainville if only they were not held back by politicians. As against this, there is little doubt that heavy-handed actions by the security forces - primarily, it seems, the police mobile squad, but also the PNGDF - did much to alienate villages and catalyse demands for secession.

In June 1989 the government declared a state of emergency on Bougainville. Police Commissioner Tohian was made controller of the state of emergency with the PNGDF commander on Bougainville his deputy. Diro, whose decision to cross the floor of parliament had resulted in a change of government, became minister of state and chairman of the parliamentary National Emergency Committee, and later, for a while, deputy prime minister. Diro's comparatively 'hard line' approach to the Bougainville situation was indicated in a statement he made in parliament in proposing the extension of the state of emergency - that 'It is a military problem. It is no longer a police law and order problem' - and in instructions passed on to the Bougainville commander, Colonel Dotaona, which were leaked to the press (see Post-Courier 12, 27 July 1989).

At the end of 1989 the Bougainville mine, which had provided Papua New Guinea with around 40 per cent of its exports and about 17 per cent of its government revenue, was 'mothballed'. The following month cabinet approved an 'all out war' against the rebels; the military option, Prime Minister Namaliu declared, is now the only option. 
Yet shortly after this intensification of the conflict a ceasefire was negotiated and the government agreed to the withdrawal of troops. This decision was not well received within the security forces, and although it was apparently intended by the government that the provincial police establishment remain to provide some semblance of law, Tohian ordered the early removal of all police, as well as the army, leaving the province virtually in the hands of the BRA. In submissions to an Australian parliamentary committee the action was described as 'a fairly serious breakdown in the control by the Papua New Guinean Government of its force' and bound to lead to chaos (JCFADT, Hearings, 22 October 1990, pp.752, 783-84).

Subsequently, on his way from a party in Port Moresby, Tohian called over his car radio for police and army personnel to arm themselves, arrest the prime minister, and take over the government. He and the officer in charge of the police riot squads were arrested and initially charged with treason, but the incident was not taken very seriously (being commonly referred to as 'the barbecoup') and the charges were subsequently dropped. (In 1992 Tohian was elected to the National Parliament and became minister for Defence.)

Two months after the withdrawal of the security forces, with negotiations for a settlement of the conflict failing to materialise, the national government cut off communications with Bougainville and imposed 'selective economic sanctions'. This action, announced by the acting prime minister, Diro, shortly after Prime Minister Namaliu left on an overseas trip, was seen by some as a deliberate attempt to undermine proposed peace talks (see Australian 3 May 1990; May and Spriggs 1990:113). Two days later the BRA made a unilateral declaration of independence for the 'Republic of Meekamui'. Among those named in the interim government of the republic, the 'minister for defence and police', Joe Pais, and the commander of the BRA, Sam Kauona, were both former PNGDF officers.

In September 1990 PNGDF troops landed on Buka Island in the north, following a request from local leaders, and the BRA was reported to have surrendered control of Buka soon after. The PNGDF was supported by a locally-organised Buka Liberation Front (BLF); (the BLF chairman described the front as an 'authorised unauthorised security force' sanctioned by the PNGDF and the government) though according to one account many on Buka 'feared the BLF more than the BRA and Defence Force soldiers' (Spriggs 1992:12; also see Post-Courier 19 December 1990). However, the arrival of troops on Buka did little to resolve the situation, which Spriggs (1992:12) described as 'a state of civil war, with fighting between the BRA and the BLF all over the island and the PNGDF seemingly taking little part in proceedings'. On Buka there were mounting accusations of human rights violations and military action against civilian targets; an 
Amnesty International report in November 1990 listed nineteen cases of 'extrajudicial execution' and over fifty cases of torture and ill-treatment by the security forces, as well as abuses by the BRA (Amnesty International 1990b. Also see Spriggs and Denoon 1992). After a boat carrying supplies, authorised by the prime minister, had been prevented from sailing by the PNGDF commander on Buka, who threatened to fire on it, the Times of Papua New Guinea (13 December 1990) commented: 'Confusion reigns . . . There does not seem to be any clear directives $[s i c]$ as to who is in authority ...'

In early 1991 a second round of peace talks was held, resulting in the Honiara Declaration, which recorded the two parties' commitment to a peaceful resolution of the conflict. Among other things the Honiara Declaration agreed to the establishment of a civilian Task Force, appointed by the minister for Provincial Affairs in consultation with a Bougainville Interim Legal Authority, to co-ordinate the restoration of services, and to accept a Multinational Supervisory Team (MST) to oversee the process of reconciliation and rehabilitation. While negotiations over the implementation of the Honiara Declaration were still proceeding, however, and with Diro again acting prime minister, some 300 PNGDF soldiers, under the command of Colonel Nuia, landed on north Bougainville and launched an operation against the BRA. Nuia claimed that the troops had been requested by local chiefs, but his action violated the terms of the Honiara Declaration and had not been authorised by the government. He came under strong criticism, especially from Momis, who described the incursion as 'totally illegal ... totally irresponsible' and likely to jeopardise peace initiatives. Momis called for the sacking of officers involved. In the event, Nuia received a reprimand, but the operation was retrospectively endorsed by cabinet.

In the following months the extent of the growing tension between civil and military authorities in relation to Bougainville became evident on a number of occasions. In May, responding to Momis's attacks on Nuia's 'invasion' of Bougainville the previous month, an army major publicly accused the minister of promoting secession and being a BRA collaborator (Post-Courier 17 May 1991). And on Buka, Nuia physically attacked a leading member of the civilian Task Force and had another arrested and charged with sedition. Not surprisingly the civilian administrator on Buka expressed himself as not happy with the working relationship between the military and the Task Force. PNGDF opposition to the idea of a MST was also a reason for its failure to materialise.

Nuia's somewhat erratic behaviour had already caused some concern among the Defence establishment and in June 1991 his unauthorised disclosure, to an Australian television reporter, concerning the use of Australian-supplied helicopters on Bougainville (see May 1993:22, 65), embarrassed the government and 
finally led to his dismissal. Momis said: 'If we don't put a stop to it, we cannot stop a coup' (Post-Courier 25 June 1991). (Subsequently Nuia challenged the legality of the action and in 1992 was reinstated and put in charge of Special Projects.).

Resentment in military and defence circles of what was seen as indecision and political interference in the handling of the Bougainville situation was sharpened by Nuia's sacking and was expressed in calls for clear directions on the specific role of PNGDF commander on Bougainville and his relation to the Task Force, and in reports that the PNGDF strength on Bougainville was 'being scaled down drastically' (Post-Courier 11 July 1991).

But the removal of Nuia and the briefing of the new PNGDF commander on Bougainville did not resolve the tensions between military and civilian officials. In July 1991, on the eve of further peace talks, it was announced that the Bougainville civilian administrator had imposed a curfew on parts of Buka and requested the government to withdraw the security forces from north Bougainville back to Buka. Subsequently it was reported that the security forces had imposed a new blockade on Bougainville, 'as a protest over what they claimed to be lack of consultation with them about the national Government's restoration program particularly over the co-ordination of ship and aircraft undertaking the restoration exercise' (Post-Courier 24 December 1991). Ships and aircraft were being prevented from travelling regardless of whether they had authorisation from civilian officials. One of the casualties of this action was a chartered aircraft which was to have taken Bougainville leaders to Honiara for talks with a national government delegation. The following year an international delegation of church leaders, whose visit to Bougainville had been authorised by the national government, was turned away by the security forces, causing the Post-Courier's editorial writer to ask, 'Who controls Bougainville?... What authority does the national Government have over the military if its decisions about visits are going to be overturned?' (21 October 1992).

In 1992-93 the Bougainville conflict spilled over the international border between Papua New Guinea and the Solomon Islands, when PNGDF troops launched several unauthorised raids into the Solomon Islands in pursuit of BRA supporters. On one occasion shots were exchanged between Papua New Guinea security forces and Solomon Islands police, and on another the Solomon Islands island of Oema was 'annexed' by PNGDF troops. Echoing the earlier PostCourier editorial, a Sydney Morning Herald editorial (16 April 1993) asked:

What is going here? Who is calling the shots? ... Increasingly [the PNGDF] will equate its own worth, its very identity and honour with achieving a victory, whatever the cost. In so doing it will grow less responsible to central control. 


\section{Conclusion}

On the eve of independence, many, especially among Papua New Guinea's emerging political leaders, looked with some apprehension to the future role of the PNGDF. Well funded by the colonial government, well trained and possessing a degree of cohesion unusual in the fragmented society of the emerging state, and actively involved in village-level civic action, the military was seen by some as a potential challenge to the authority of an independent government and a threat to the continuation of a democratic political system. Not all of those who foresaw a political role for the military, however, anticipated a coup-style takeover. Hastings, for example, suggested that 'Australian democracy' was unlikely to take root and that 'we might be sensible to look towards 'guided democracy', to a presidential system, to a strong army loyal to a strong central executive' (1969:191-92. Also see Nelson 1972:208).

Concern about the future role of the Defence Force was reflected in the independence constitution, which rejected the idea of the military's participation in government and defined the Defence Force's primary function as that of defending the country against external threat, placing restrictions on its use for internal security purposes.

Contrary to pessimistic predictions, after independence Papua New Guinea's democratic system prospered, and in the absence of external threat the military languished, notwithstanding substantial financial assistance through Australia's Defence Co-operation Program. But within a decade of independence, growing problems of lawlessness and disorder began to threaten the position of national political leaders, and even some who had earlier looked apprehensively at the PNGDF, began to call for an expanded role of the Defence Force in assisting police to maintain internal security.

The first rift between civil and military leaders - the so-called Diro Affair of 1977 - was not long in coming; but though it generated rumours of an impending coup it proved to be inconsequential. On the other hand, the resignation of several senior officers, including the deputy commander and the commander, to pursue careers in civil politics, established an early precedent and suggested a possible safety-valve against the build-up of military antagonism towards the civilian government. There was also, from the early 1980s, clear evidence of a politicisation of at least the senior levels of the PNGDF.

With a resurgence of tribal fighting and a growing problem of criminality, more and more politicians looked to the military to support the increasingly inadequate attempts of the police to contain lawlessness and maintain the authority of the state. From 1984 the army was regularly involved in 'law and order' operations and there was growing acceptance that the PNGDF's role in internal security was 
likely to be more significant than its function of safeguarding the country against external threat.

In this respect, the emergence of the Bougainville crisis was a watershed in changing perceptions of the PNGDF. What began as a police action against disgruntled landowners developed into a full-blown insurrection in which the PNGDF was called upon to maintain the integrity of the Papua New Guinea state. In the process, severe doubts have been cast upon the capacity of the Defence Force to act in internal security situations. A belief within the security forces that they have been deprived of adequate funding and have been subjected to 'political' interference predates the Bougainville crisis but has been exacerbated by events on Bougainville since 1988. The effects of such feelings have been a growing tension in relations between military personnel and civil authorities, factionalism within the PNGDF's senior command structure, and a general lowering of morale and discipline. Notwithstanding this, by the early 1990s, with the Bougainville conflict still not resolved and growing threats to the authority of the state from urban and rural lawlessness, a series of reviews and summit meetings resulted in a significant shift in perceptions of the role of the PNGDF, placing primary emphasis on its role in maintaining internal security.

Such developments have coincided with an apparent tendency towards tighter social control in Papua New Guinea and an expressed admiration of Indonesian, Singaporean and Malaysian models (see May 1993:74). In 1992 this prompted a group of NGO and church organisations to warn against an 'increasing and dangerous trend towards the militarisation of [Papua New Guinea] society'; 'We need not have a military coup', their statement said, 'to militarise society' (PostCourier 7 August 1992).

The spectre of a military coup has been raised on several occasions. Indeed, in many respects Papua New Guinea presents the classic preconditions for military intervention (see chapter 1). Most observers, however, continue to see a coup as a remote possibility. This is not least because of the logistic difficulties which an attempted coup would pose for a relatively small army with limited transport capabilities in a physically and socially fragmented society in which even popularly elected national and provincial governments have difficulty maintaining their authority. Beyond this, even in relation to Bougainville the military's corporate interests do not appear to have been well defined in political terms, and electoral politics has provided a well-trodden exit route for soldiers with personal political ambitions. But while the military's subordination to civilian authority seems to be fairly well assured in the foreseeable future, the PNGDF has become politicised at senior levels and appears increasingly prone to challenge government decisions. If the integrity of the Papua New Guinea state becomes more 
dependent on the support of the security forces in the face of growing law and order problems, these tendencies may increase. Such a development would involve a slight shift along the 'civilocracy'/'militocracy' continuum (Bebler 1990), but, at least in terms of participation and competition, within a continuing essentially democratic political framework. 